\title{
Justification of antiadhesive components choice for the composition of effervescent tablets with thick extract of betula verrucosa leaves
}

\author{
O. O. Chumak, Ye. A. Bezrukavyi \\ National University of Pharmacy, Kharkiv, Ukraine
}

Urolithiasis and inflammatory diseases of the urinary system are of great importance in recent times. Only urolithiasis affects about $15 \%$ of the population. Therefore, the development of new domestic drugs for the treatment of urinary system disorders is an urgent task. In the pharmaceutical market of Ukraine, there are medicinal products of plant origin that exhibit antispasmodic, antiseptic, anti-inflammatory, diuretic effects, as well as dissolve concrements and eliminate them from urine.

Aim of the work. To determine the optimal composition of antiadhesive components for the production of effervescent tablets with a thick extract of silver birch leaves.

Materials and methods. During the experiment, the effects of macrogol 6000 , macrogol 4000, glycine and fumaric acid on the technological characteristics of the model granulates and the resulting tablets were investigated. In the experiments, modern equipment and techniques were used to study tablets ejection force, granules fluidity, strength of tablets, disintegration of tablets.

Results. Macrogols of 4000 and 6000 showed the best results in all studies. With satisfactory flow rates, they showed a high anti-adhesive ability and the resulting tablets had the highest rates of crushing resistance. Macrogol 4000 has the most optimal anti-adhesive properties, while the most intense reduction in the pressure of pushing tablets from the matrix is observed at its content under $4 \%$. Macrogol 6000 has satisfactory lubricating properties, but at a concentration of $6 \%$. Thus, based on the performed studies, it has been found that for the production of effervescent tablets with a thick extract of silver birch leaves it is advisable to use the macrogol 4000 (or macrogol $6000)$ as the antiadhesive component.

Conclusions. Hydrophilic lubricants (macrogols 4000 and 6000, glycine, fumaric acid) were used to determine the optimal composition of anti-adhesive excipients to produce effervescent tablets with a thick extract of silver birch leaves, among which the best results for all were shown by macrogols 4000 and 6000 . According to the results of the research, as the antiadhesive component for the preparation of tablets with thick extract of silver birch leaves, macrogol 4000 was selected which showed high antiadhesive ability and the obtained tablets had the highest indices for resistance to crushing, while the most intense reduction of the pressure of pushing out tablets from the matrix was observed at macrogol 4000 concentration up to $4 \%$ in tablet mass.

Обґрунтування вибору антиадгезійних компонентів у складі шипучих таблеток із густим екстрактом листя берези бородавчастої

\section{О. О. Чумак, Є. А. Безрукавий}

Нині на сечокам'яну хворобу страждає майже 15 \% населення. Тому розробка нових вітчизняних лікарських засобів для лікування порушень сечовидільної системи є актуальним завданням. На фрармацевтичному ринку України присутні лікарські препарати рослинного походження, що виявляють спазмолітичну, антисептичну, протизапальну, сечогінну дії, а також сприяють виведенню сечових конкрементів та їх розчиненню. Серед них на особливу увагу заслуговують препарати, що містять поліфеноли. Ці сполуки поширені в рослинному світі, добре вивчені в хімічному та фармакологічному відношенні, але, незважаючи на це, тривають інтенсивні дослідження зі створення нових поколінь лікарських засобів на їхній основі.

Мета роботи - визначити оптимальний склад антиадгезійних компонентів для отримання шипучих таблеток із густим екстрактом листя берези бородавчастої.

Матеріали та методи. Протягом експерименту досліджували вплив макроголу 6000, макроголу 4000, гліцину та кислоти фумарової на технологічні характеристики модельних гранулятів та таблеток, що одержали. У дослідах використовували сучасне обладнання та методики для дослідження тиску виштовхування таблеток із матриці, текучості грануляту, міцності таблеток до роздавлювання, розпадання таблеток.

Результати. Оптимальні показники за всіма дослідженнями показали макроголи 4000 та 6000 . При задовільних показниках текучості вони показали високу антиадгезійну здатність, і таблетки, що отримали, мали найвищі показники за стійкістю до роздавлювання. Оптимальними антиадгезійними властивостями володіє макрогол 4000, при цьому найінтенсивніше зниження тиску виштовхування таблеток із матриці відбувалося до 4 \% його вмісту. Задовільними змащувальними властивостями володіє макрогол 6000 , але при

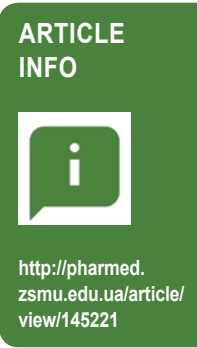

UDC: $615.254: 615.453 .6: 615.014 .21$

DOI: $10.14739 / 2409-2932.2018 .3 .145221$

Current issues in pharmacy and medicine: science and practice 2018; 11 (3), 286-291

Key words: tablets, birch, plant leaves.

E-mail: genya_b@ua.fm

Received: 20.08.2018 // Revised: 29.08.2018 // Accepted: 05.09.2018 
концентрації 6 \%. Отже, на підставі досліджень встановили, що для виробництва шипучих таблеток із густим екстрактом листя берези бородавчастої доцільно використовувати як антиадгезійний компонент макрогол 4000 (або макрогол 6000).

Висновки. Для визначення оптимального складу антиадгезійних добавок для отримання шипучих таблеток із густим екстрактом листя берези бородавчастої використано гідрофрільні змащувальні речовини (макроголи 4000 та 6000, гліцин, кислота фрумарова), серед яких оптимальні показники за всіма дослідженнями показали макроголи 4000 та 6000 . За результатами досліджень як антиадгезійний компонент для отримання таблеток із густим екстрактом листя берези бородавчастої обрано макрогол 4000, який виявив високу антиадгезійну здатність, і таблетки мали найвищі показники за стійкістю до роздавлювання, при цьому найінтенсивніше зниження тиску виштовхування таблеток із матриці відбувалось при концентрації макроголу 4000 до 4 \% у таблетковій масі.

Ключові слова: таблетки, береза, рослин листя.

Актуальні питання фрармацевтичної і медичної науки та практики. - 2018. - Т. 11, № 3(28). - С. 286 -291

\section{Обоснование выбора антиадгезионных компонентов в составе шипучих таблеток с густым экстрактом листьев березы бородавчатой}

\section{А. А. Чумак, Е. А. Безрукавый}

Мочекаменная болезнь и воспалительные заболевания мочевыделительной системы в последнее время приобретают большое значение. Только мочекаменной болезнью страдает около 15 \% населения. Поэтому разработка новых отечественных лекарственных средств для лечения нарушений мочевыделительной системы является актуальной задачей. На фрармацевтическом рынке Украины присутствуют лекарственные препараты растительного происхождения, которые проявляют спазмолитическое, антисептическое, противовоспалительное, мочегонное действие, а также способствуют выведению мочевых конкрементов и их растворению. Среди них особого внимания заслуживают препараты, содержащие полифенолы. Эти соединения широко распространены в растительном мире, хорошо изучены в химическом и фармакологическом отношении, но, несмотря на это, продолжаются интенсивные исследования по созданию новых поколений лекарственных средств на их основе.

Цель работы - определить оптимальный состав антиадгезионных компонентов для получения шипучих таблеток с густым экстрактом листьев березы бородавчатой.

Материалы и методы. В течение эксперимента исследовали влияние макрогола 6000, макрогола 4000, глицина и кислоты фрумаровой на технологические характеристики модельных гранулятов и полученных таблеток. В опытах использовали современное оборудование и методики для исследования давления выталкивания таблеток из матрицы, текучести гранулята, прочности таблеток к раздавливанию, распадаемости таблеток.

Результаты. Оптимальные показатели по всем исследованиям показали макрогол 4000 и 6000. При удовлетворительных показателях текучести они показали высокую антиадгезионную способность, и полученные таблетки имели высокие показатели по устойчивости к раздавливанию. Оптимальными антиадгезионными свойствами обладает макрогол 4000, при этом наиболее интенсивно снижение давления выталкивания таблеток из матрицы проходило до 4 \% его содержания. Удовлетворительными антифррикционными свойствами обладает макрогол 6000 , но при концентрации $6 \%$. На основании проведенных исследований установлено, что для производства шипучих таблеток с густым экстрактом листьев березы бородавчатой целесообразно использовать в качестве антиадгезионного компонента макрогол 4000 (или макрогол 6000).

Выводы. Для определения оптимального состава антиадгезионных добавок для получения шипучих таблеток с густым экстрактом листьев березы бородавчатой были использованы гидрофильные смазывающие вещества (макрогол 4000 и 6000, глицин, кислота фрумаровая), среди которых оптимальные показатели по всем исследованиям показали макрогол 4000 и 6000 . По результатам исследований в качества антиадгезионного компонента для получения таблеток с густым экстрактом листьев березы бородавчатой был выбран макрогол 4000, который проявил высокую антиадгезионную способность, и полученные таблетки имели высокие показатели по устойчивости к раздавливанию, при этом наиболее интенсивно снижение давления выталкивания таблеток из матрицы проходило при концентрации макрогола 4000 до 4 \% в таблеточной массе.

Ключевые слова: таблетки, береза, растений листья.

Актуальные вопросы фрармацевтической и медицинской науки и практики. - 2018. - Т. 11, № 3(28). - С. 286 -291

\section{Introduction}

Nature has been the source of drugs for thousands of years and an impressive number of modern drugs has been isolated from raw materials of plant origin. Plants served as a source of new pharmaceutical products and inexpensive source materials for the synthesis of some well-known drugs. Natural products and their derivatives are the basis of more than $50 \%$ of medications in clinical practice worldwide [1,2].

When using herbal medications, it is possible to take them for a long time because they rarely cause complications, especially allergic reactions, in contrast to synthetic drugs, so they can be prescribed for long-term use with the task of minimizing negative effects on the patient's body due to mild therapeutic action, a small number of contraindications along with high efficiency, which justifies their widespread use in the treatment of various diseases. The components of medicinal plant material according to the chemical structure are similar or even identical to the physiologically active substances of the human body. Therefore, medicines of plant origin are more physiologically included in the biochemical processes of the human body than chemical, alien to the body, synthetic drugs [1]. Physiologically, active substances of phytopreparations exhibit diversified pharmacological activity, 
contributing to the effective treatment of many diseases and giving almost no adverse effects on the human body [1] However, despite the undeniable advantages, the demand for domestic phytopreparations exceeds their availability, which explains the relevance of the development of new drugs on the basis of medicinal plant material, including ones for use in urology $[1,2]$.

Urolithiasis and inflammatory diseases of the urinary system are of great importance in recent times because the poor ecological situation and the consumption of low-quality food and water leads to an increase in the number of patients with pyelonephritis, cystitis, urethritis and urolithiasis. Only urolithiasis affects about $15 \%$ of the population. Therefore, the development of new domestic medicines for the treatment of urinary system disorders is an urgent task $[3,4]$.

In the pharmaceutical market of Ukraine, there are medicinal products of plant origin that exhibit antispasmodic, antiseptic, anti-inflammatory, diuretic effects, as well as promote the removal of stones and their dissolution. The action of these medicinal products is due to the biologically active substances that are part of their composition [2]. Among them, special attention should be paid to preparations containing polyphenols (flavonoids, phenolcarboxylic acids, tannins, etc.). These compounds are widespread in the plant world, well studied in the chemical and pharmacological terms, but despite this, intensive studies are continuing to create new generations of drugs on their basis.

Particular attention among plants containing polyphenols in their composition should be paid to the silver birch (Betula verrucosa), the leaves of this plant contain a significant number of flavonoids [1,6]. The thick extract of birch leaves exhibits anti-inflammatory properties, expresses hypoasotemic action, reduces renal edema in acute renal failure, and promotes the removal of urinary concrements $[1,3,4,7]$. Therefore, considering the effectiveness and complex effect on the urinary system of the thick extract of silver birch leaves, it is reasonable to use it as an active pharmaceutical ingredient in the creation of new drugs for use in urological practice.

The development of drugs with controlled release of active substances remains relevant to date. These medications include instant (effervescent) tablets that differ from traditional solid dosage forms by rapid onset of therapeutic effect. In developing the production technology of tableted dosage forms the question arises in the use of anti-adhesive components that play an important role in the production of solid dosage forms. When working with modern high-performance tablet presses there is a friction between the side surfaces of the tablet and the matrix, which leads to the heating of the latter. Consequently, worsen technological characteristics of tablet mass and increases reactivity of the components, which could lead to jamming of pressing tool of tablet machines unwanted interaction of gas-forming components of rapid-soluble tablets. Therefore, in these cases, anti-adhesive additives should be used that reduce the friction to an acceptable level.

The modern nomenclature of anti-adhesive excipients for the production of solid dosage forms is quite large, but most of them are insoluble in water (stearic acid and its salts, talc and aerosil). The method of using rapid-soluble tablets involves dissolving them in a glass of water, and using hydrophobic anti-adhesion components, an unpleasant film from them will be formed on the surface. In addition, the surface of the tablet will have a hydrophobic layer, which will reduce its rate of dissolution in water.

To obtain rapid-soluble (effervescent) tablets, anti-adhesive excipients, which, together with the chemical indifference, will have good lubricating, glidant properties and thus well dissolve in water should be selected.

\section{The aim of the work}

To determine the optimal composition of anti-adhesive excipients to produce effervescent tablets with a thick extract of silver birch leaves. Depending on the concentration of the antifriction components in the mass for tableting, to evaluate the ability to reduce friction between the tablet and the die by measuring the pressure of pushing out the tablets from the die, to determine the effect of the anti-adhesive components on the mechanical strength of the tablets, the flowabilities of granulates and disintegration.

\section{Materials and methods}

In this work antiadhesive excipients, which are most often used in the technology of fast-release (effervescent) tablets: macrogol 6000, macrogol 4000, glycine, fumaric acid were investigated. These substances are well soluble in water, pharmacologically indifferent and have good lubricating and glidant properties.

Model granules were prepared by a separate method: sodium bicarbonate and citric anhydrous acid were loaded in the mixer, carefully mixed to homogeneity and moisturized with a solution of water-soluble polyvinylpyrrolidone (Kollidon $^{\circledR} 25$, BASF) in ethanol $96 \%$, mixed to homogeneity and granulated through a sieve with a diameter of holes $2 \mathrm{~mm}$, dried to a residual moisture of $1 \%$ and calibrated on a sieve with a diameter of holes $1.5 \mathrm{~mm}$ - gas-forming components granulate was obtained. Into another mixer loaded lactose monohydrate, aspartame, flavoring, mixed thoroughly to homogeneity, moisturized with a solution of thick extract of leaves of silver birch, Kollidon ${ }^{\circledR} 25$ and PEG-40 (hydrogenated castor oil) in purified water. The resulting mass was stirred to homogeneity and granulated through a sieve with a hole diameter of $2 \mathrm{~mm}$, dried to a residual moisture of $1 \%$, and calibrated on a sieve with a diameter of holes $1.5 \mathrm{~mm}$ [8-10]. The resulting granulate was added to the gas-forming components granulate and mixed to homogeneity. Prior to pressing the mass was powdered with anti-adhesive ingredients (macrogol 6000, macrogol 4000, glycine, fumaric acid) in various concentrations. The concentration of anti-adhesive components was selected in the range of 1 to $8 \%$.

The determination of the force of pressing and the pushing-out force was carried out on a laboratory hydraulic press equipped with two pressure measuring gauges with measuring limits at $150 \mathrm{kgf} / \mathrm{cm}^{2}$ and $10 \mathrm{kgf} / \mathrm{cm}^{2}$ at effort on the surface of the punches. For pressing, the tablet mass was loaded into 
the die canal, an upper punch was installed from above, and pressure was applied to the system by pumping a working fluid with a small piston, and at this the large piston (plunger) rises and compresses the sample. The pressing pressure was the same for all mixtures and amounted to $130 \mathrm{kgf} / \mathrm{cm}^{2}$ (readings of the pressure gauge of the hydraulic press), corresponding to a pressure of $1093.3 \mathrm{kgf} / \mathrm{cm}^{2}$ directly on the tablet. When the set pressure was reached, a crane was opened to discharge the working fluid into the expense capacity, the plunger of the press was lowered and the upper punch was removed, leaving the compressed tablet and the lower punch in the die. Again, pressure was applied to the system with the help of a small piston and the pressure of the tablet ejection from the die was fixed on the pressure gauge. Calculation of the pressure of pressing and pushing the tablets out from the die was carried out according to the following formula:

$$
\mathrm{P}_{\mathrm{t}} \cdot \mathrm{d}_{\mathrm{t}}^{2}=\mathrm{P}_{\mathrm{m}} \cdot \mathrm{d}_{\mathrm{pl}}^{2},
$$

$\mathrm{P}_{\mathrm{t}}$ : pressure of pressing (pushing out) of a tablet, $\mathrm{kgf} / \mathrm{cm}^{2}$ (or $0.0980665 \mathrm{MPa}$ );

$\mathrm{d}_{\mathrm{t}}$ : diameter of the pressed tablet, $\mathrm{mm}$;

$\mathrm{P}_{\mathrm{m}}$ : pressure on a pressure gauge of a hydraulic press, $\mathrm{kgf} / \mathrm{cm}^{2}$; $d_{p l}^{m}:$ diameter of the plunger of the hydraulic press, $\mathrm{mm}$.

For the study, weighed a sample of 2.5 grams and took a press tool with a diameter of $20 \mathrm{~mm}$. The calculation of pressure of pressing and pushing the tablets out was carried out using the formula.

Tablets obtained on laboratory hydraulic press were subjected to disintegration test. For this, one tablet was placed in a glass of $200 \mathrm{ml}$ of water purified at a temperature of $(20 \pm 5){ }^{\circ} \mathrm{C}$ according to general monograph "Tablets" of SPU [5].

The flowability measurements were carried out by the method of a funnel with a vibration device on the Pharma Test device, the diameter of the hole of which reservoir is $12 \mathrm{~mm}$ (SPU 2 ed. 2.9.16 N) [5]. The granules were transported to the funnel, having previously closed the damper, exposed to vibration for 20 seconds and opened the damper. Measured the time required for the complete outflow of the sample from the funnel.

The determination of mechanical strength of tablets obtained was performed according to SPU 2 ed. 2.9.8 [5] technique on a fully automated Tablet Four-use Tester with an indication of the average, minimum and maximum measured power in Newtons.

\section{Results}

The first stage of the study was to determine the fluidity of granules, depending on the concentration of anti-adhesive components. The results of the study are shown in Fig. 1.

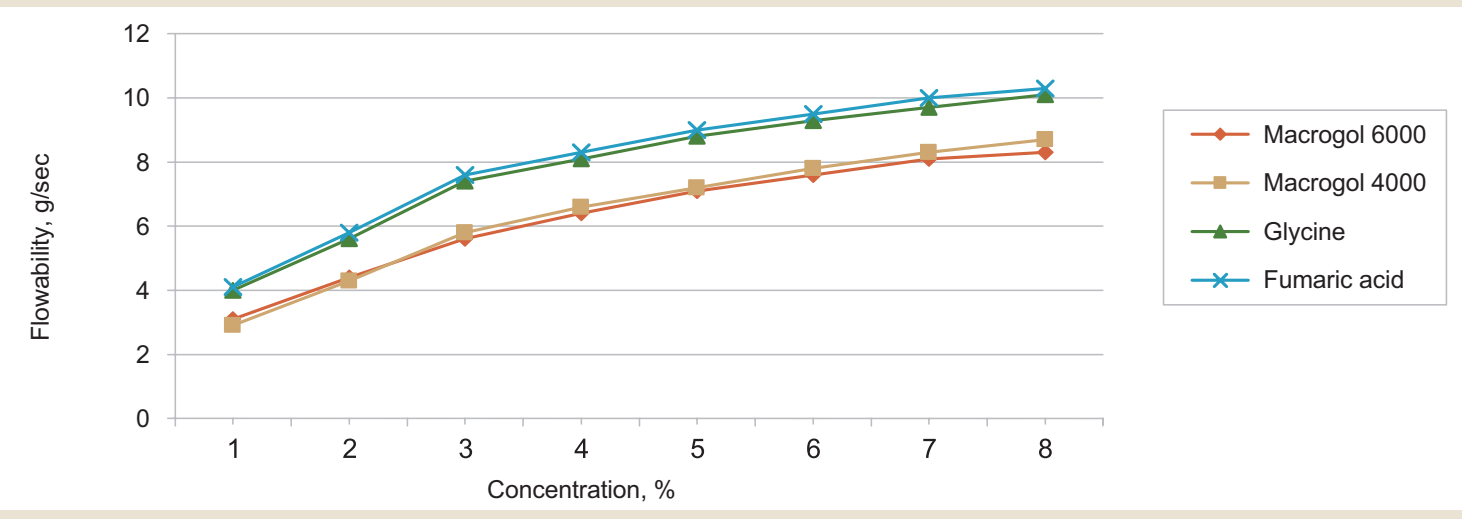

Fig. 1. Flowability of granulate $(\mathrm{g} / \mathrm{s})$ at concentration of anti-adhesive components $(\%), n=5, P \leq 0.05$.

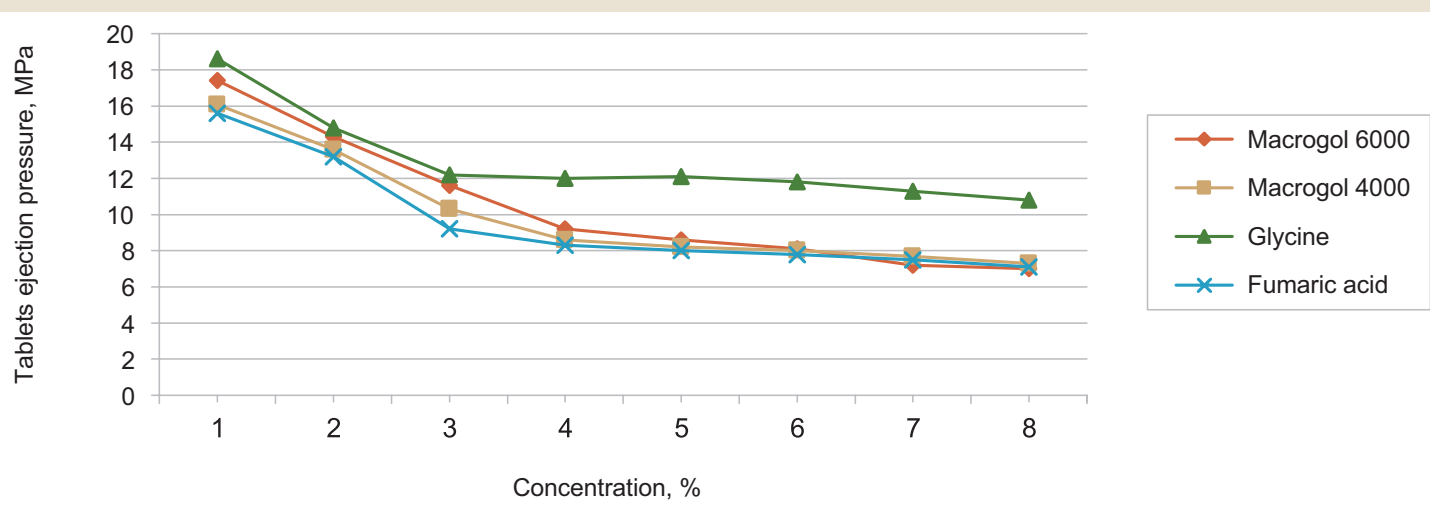

Fig. 2. Pushing-out pressure of tablets $(\mathrm{MPa})$ at the concentration of antiadhesive components $(\%), n=5, P \leq 0.05$. 
Table 1. Disintegration times of tablets $(n=5, P \leq 0.05)$

\begin{tabular}{|l|l|l|l|l|l|l|l|l|l|}
\multirow{2}{*}{ № } & \multirow{2}{*}{$\begin{array}{l}\text { The name of the anti-adhesive } \\
\text { component }\end{array}$} & \multicolumn{6}{|l|}{ Disintegration of tablets (min) at concentration of antiadhesive components (\%) } \\
\cline { 3 - 11 } & 1 & 2 & 3 & 4 & 5 & 6 & 7 & 8 \\
\hline 1 & Macrogol 6000 & $2.62 \pm 0.11$ & $2.68 \pm 0.09$ & $2.58 \pm 0.10$ & $2.69 \pm 0.12$ & $2.73 \pm 0.09$ & $2.59 \pm 0.11$ & $2.75 \pm 0.12$ & $2.69 \pm 0.11$ \\
\hline 2 & Macrogol 4000 & $2.42 \pm 0.11$ & $2.39 \pm 0.12$ & $2.46 \pm 0.09$ & $2.36 \pm 0.11$ & $2.44 \pm 0.10$ & $2.52 \pm 0.11$ & $2.48 \pm 0.09$ & $2.62 \pm 0.12$ \\
\hline 3 & Glycine & $2.48 \pm 0.12$ & $2.38 \pm 0.10$ & $2.52 \pm 0.13$ & $2.58 \pm 0.12$ & $2.64 \pm 0.11$ & $2.66 \pm 0.10$ & $2.72 \pm 0.12$ & $2.74 \pm 0.13$ \\
\hline 4 & Fumaric acid & $2.41 \pm 0.11$ & $2.42 \pm 0.12$ & $2.44 \pm 0.11$ & $2.38 \pm 0.09$ & $2.46 \pm 0.10$ & $2.52 \pm 0.12$ & $2.46 \pm 0.11$ & $2.58 \pm 0.11$ \\
\hline
\end{tabular}

Table 2. Mechanical strength of tablets $(n=5, P \leq 0.05)$

\begin{tabular}{|l|l|l|l|l|l|l|l|l|l|}
\hline \multirow{2}{*}{$№$} & \multirow{2}{*}{$\begin{array}{l}\text { The name of the anti-adhesive } \\
\text { component }\end{array}$} & \multicolumn{6}{|l|}{ Mechanical strength of tablets (N) at concentration of antiadhesive components (\%) } \\
\cline { 3 - 11 } & $\mathbf{1}$ & $\mathbf{2}$ & $\mathbf{3}$ & $\mathbf{4}$ & $\mathbf{5}$ & $\mathbf{6}$ & $\mathbf{7}$ & $\mathbf{8}$ \\
\hline 1 & Macrogol 6000 & $151.2 \pm 5.7$ & $150.8 \pm 6.2$ & $148.3 \pm 6.1$ & $145.6 \pm 5.9$ & $145.2 \pm 6.8$ & $144.2 \pm 5.9$ & $144.6 \pm 5.3$ & $143.1 \pm 6.4$ \\
\hline 2 & Macrogol 4000 & $149.5 \pm 5.9$ & $149.9 \pm 6.2$ & $150.2 \pm 6.7$ & $150.0 \pm 5.6$ & $148.3 \pm 5.9$ & $146.8 \pm 6.7$ & $146.2 \pm 6.6$ & $145.5 \pm 5.7$ \\
\hline 3 & Glycine & $119.6 \pm 4.4$ & $118.8 \pm 5.2$ & $118.6 \pm 4.8$ & $116.7 \pm 5.0$ & $115.9 \pm 5.3$ & $115.5 \pm 4.9$ & $114.3 \pm 5.1$ & $113.0 \pm 4.9$ \\
\hline 4 & Fumaric acid & $122.3 \pm 4.9$ & $120.5 \pm 4.4$ & $117.3 \pm 5.3$ & $115.9 \pm 4.9$ & $113.0 \pm 4.8$ & $112.6 \pm 5.2$ & $111.2 \pm 4.9$ & $110.8 \pm 4.2$ \\
\hline
\end{tabular}

Next stage of the study was measurement of the pressure of pushing the tablets out from the die depending on the concentration of anti-adhesive components in the mass for tableting. The results of the test are shown in Fig. 2.

The results of the test for tablets disintegration are given in Table 1.

Since the antifriction components, which include anti-adhesives, adversely affect the mechanical strength of tablets, a study was conducted to determine the mechanical strength of the resulting tablets. The results are given in Table 2.

\section{Discussion}

Data analysis (Fig. 1, 2 and Table 1, 2) shows that the fumaric acid and glycine, on the one hand, give the best flowability performance to the granulate, but at the same time, they have the lowest strength indicators and, in appearance, did not meet the requirements - chips and cracks on the surface of tablets and bevels. Glycine showed the worst lubricating properties in contrast to fumaric acid, which showed the best reduction in the pressure of pushing tablets out of the die.

Tests of tablets disintegration were able to withstand all samples of the tablets and this test did not detect a particular leader, as the disintegration time of all samples was within 3 minutes.

The most suitable indicators for all studies had macrogols 4000 and 6000 . With satisfactory flow rates, they showed a high anti-adhesive ability and the resulting tablets had the highest rates for mechanical strength. As can be seen from Fig. 2, macrogol 4000 possesses the most optimal anti-adhesive properties, with the most intense reduction in the pressure of pushing tablets from the die was observed at $4 \%$ of its content. Satisfactory lubricating properties has macrogol 6000 , but at a concentration of $6 \%$.
Thus, based on the performed studies, it was found that for the production of effervescent tablets with a thick extract of silver birch leaves, it is advisable to use macrogol 4000 (or macrogol 6000) as an antiadhesive component.

\section{Conclusions}

1. Hydrophilic lubricants (macrogols 4000 and 6000, glycine, fumaric acid) were used to determine the optimal composition of anti-adhesive excipients to produce effervescent tablets with a thick extract of silver birch leaves, among which the best results for all indicators had macrogols 4000 and 6000 .

2. According to the results of the study, as the antiadhesive component for obtaining tablets with a thick extract of silver birch leaves, macrogol 4000 has been chosen which showed high antiadhesion ability and the resulting tablets had the highest indices for the mechanical strength, while the most intense reduction in the pressure of pushing the tablets from the die was at Macrogol 4000 concentration in tablet mass 4\%.

Prospects for further research. The results are the basis for the development of the optimal composition of effervescent tablets with thick extract of betula verrucosa leaves.

Conflicts of interest: authors have no conflict of interest to declare. Конфлікт інтересів: відсутній

Information about authors:

Chumak O. O., Aspirant of the Department of Industrial Pharmacy, National University of Pharmacy, Kharkiv, Ukraine.

Bezrukavyi Ye. A., PhD, Associate Professor, Department of Industrial Pharmacy, National University of Pharmacy, Kharkiv, Ukraine.

Відомості про авторів:

Чумак О. О., аспірант каф. промислової фармації, Національний фармацевтичний університет, м. Харків, Україна. 
Безрукавий Є. А., канд. фрарм. наук, доцент каф. промислової фармації, Національний фрармацевтичний університет, м. Харків, Україна.

Сведения об авторах:

Чумак А. А., аспирант каф. промышленной фармации, Национальный фармацевтический университет, г. Харьков, Украина.

Безрукавый Е. А., канд. фарм. наук, доцент кафедры промышленной фармации, Национальный фармацевтический университет,

г. Харьков, Украина.

\section{References}

[1] Prilepskaya, E. A., \& Zajcev, A. V. (2014). Infekcii nizhnikh mochevyvodyaschikh putej: al'ternativnyj podkhod k terapii [Infections of the lower urinary tract: an alternative approach to therapy]. Russkij medicinskij zhurnal, 22(29), 2108-2111. [in Russian].

[2] Erman, M. V. (2014). Fitoterapiya v lechenii infekcii mochevoj sistemy $u$ detej [Phytotherapy in treatment of infections of urinary system in children]. E'ffektivnaya farmakoterapiya. Pediatriya, 2(16), 18-22. [in Russian].

[3] Chorna, N. S., Laryanovska, Yu. B., Gorban, O. M., Yudkevich, T. K., \& Babenko, D. M. (2012). Nefroprotektorna diia hustoho ekstraktu z lystia berezy borodavchastoi na tli rozvytku eksperymentalnoi diabetychnoi nefropatii u shchuriv [The nephroprotective effect of thick extract of silver birch leaves in the experimental diabetic nephropathy in rats]. Klinichna farmatsiia, 16, 60-65. [in Ukrainian].

[4] Neshcheret, O. I. (2005). Farmakohnostychne vyvchennia lystia berezy borodavchastoi (Avtoref. dis...kand. farm. nauk). [Pharmacog- nostic study of silver birch leaves]. (Extended abstract of candidate's thesis). Kharkiv. [in Ukrainian].

[5] Derzhavne pidpryiemstvo «Ukrainskyi naukovyi farmakopeinyi tsentr yakosti likarskykh zasobiv» (2015) Derzhavna Farmakopeia Ukrainy [The state pharmacopeia of Ukraine], (Vol. 1). Kharkiv [in Ukrainian].

[6] Derzhavne pidpryiemstvo «Ukrainskyi naukovyi farmakopeinyi tsentr yakosti likarskykh zasobiv» (2014) Derzhavna Farmakopeia Ukrainy [The state pharmacopeia of Ukraine], (Vol. 3). Kharkiv [in Ukrainian].

[7] Chumak, O., \& Bezrukaviy, Y. (2015). Doslidzhennia parametriv ekstraktsii lystia berezy borodavchastoi ta vybir optymalnoho rezhymu otrymannia ekstraktu [Investigation of the extraction parameters of silver birch leaves and selection of optimal regimen for obtaining the extract]. Viiskova medytsyna Ukrainy, 15(2), 70-75. [in Ukrainian].

[8] Chumak, O., \& Bezrukaviy, Y. (2016). Obosnovanie vybora uvlazhnitelya dlya proizvodstva shipuchikh tabletok s gustym e'kstraktom listev berezy borodavchatoj [Substantiation of the choice of the binder solution for production of effervescent tablets with the silver birch leaves thick extract]. Recept, 19(4), 450-455. [in Russian].

[9] Omelchenko, P. S., Hladukh, Ye. V., \& Burlaka, I. S. (2015). Rozrobka skladu ta obgruntuvannia tekhnolohii tabletok z hustym ekstraktom sobachoi kropyvy travy [Development of the composition and substantiation of the technology of tablets with thick extract of leonurus]. Fitoterapiia. Chasopys, 1, 70-72. [in Ukrainian].

[10] Hladukh, Ye. V., \& Omelchenko, P. S. (2015). Rozrobka tekhnolohii ta metodiv analizu tabletok z hustym ekstraktom sobachoi kropyvy [Development of technology and methods for analysis of tablets with thick extract of leonurus]. Pivdennoukrainskyi medychnyi naukovyi zhurnal, 11(11), 56-58. [in Ukrainian]. 